countries but this does not appear on balance sheet of the global corporations.

\section{Injury and globalisation}

\section{Roberts}

\section{The injury prevention community cannot overlook the consequences of macroeconomic policies}

$\mathrm{S}$ ome years ago, there was a TV advert for the Guardian newspaper, which became an advertising classic. It showed a young man, short hair, tattoo, drainpipe trousers and bovver boots, pelting towards an old man ambling his way down the street. When the lout catches up, he grabs the old man and flings him down, clearly a vicious unprovoked assault. But then the camera moves back to show the whole picture. A pile of bricks, fallen from a crane, is about to flatten the old guy. The viewers were wrong. The "lout" was saving his life. We need the whole picture in order to really know what is going on.

To prevent injury we need to understand its causes and this also requires that we look at the whole picture. The macroeconomic determinants of injury are not evident at the site of injury and are never captured by injury surveillance systems. Nevertheless, they have a huge effect on the injury incidence rate. Of these, the neoliberal trade policies that are being championed by the governments of the economically powerful nations are likely to be the most important.

\section{TRANSPORT AND GLOBAL BUSINESS}

The captains of industry are excited about policies that facilitate transnational trade because of their potential to increase profits. It is more profitable to manufacture goods in low income countries where wages are low than in high income countries where workers enjoy higher wages and standards of living. But the people in low income countries cannot afford to buy expensive manufactured goods and so the finished goods have to be transported back to markets in high income countries. Much of this so called "trade" is not international trade at all but the movement of materials within transnational corporations. Nevertheless, it requires cheap transport, which means good roads, preferably paid for by the public, and cheap fuel. If business had to pay the full social and environmental cost of transport then transnational trade would be very inefficient and there would be less enthusiasm for it. Fortunately for business, the public pays much of the costs so that transnational trade can be very lucrative.

Trade causes injury because it generates huge volumes of road traffic. Because wages are lower in Mexico it makes business sense for firms in the US to move manufacturing to Mexico. Truck miles travelled in the US have increased by $21 \%$ since the signing of the North American Free Trade Agreement. ${ }^{1}$ Similarly, in the European Union, road freight increased by $44 \%$ between 1991 and 1999. ${ }^{2}$ Per kilometre travelled, heavy goods vehicles are twice as likely to be involved in fatal road traffic crashes as cars. ${ }^{3}$ In 2000, trucks accounted for $8 \%$ of all vehicles involved in fatal crashes in the US resulting in 5282 deaths and 130000 injuries. ${ }^{4}$ In UK, heavy goods vehicles are involved in about 15000 injury crashes per year resulting in some 580 deaths. ${ }^{3}$ Over half $(58 \%)$ of cyclist deaths in inner London are due to heavy goods vehicles. ${ }^{5}$ Economic globalisation leads to more freight on longer journeys and this means more road deaths. In low and middle income countries, which bear the brunt of the global road trauma epidemic, trucks are involved in the majority of traffic crashes. In India, trucks are involved in half of crashes in cities and two thirds of crashes on highways. ${ }^{6}$ Victims are predominantly pedestrians and cyclists who are more likely to sustain serious chest and head injuries if struck by a truck than if struck by a car.

Policies that make transport cheap for business also make it cheap for everyone else and so they increase traffic across the board and not just truck traffic. The relationship between the price of transport and road deaths was shown during the 1973 Arab oil embargo when a sudden hike in oil prices resulted in a substantial fall in traffic volumes and in child pedestrian death rates. ${ }^{78}$ Fuel prices in low and middle income countries are remarkably low, with little or no fuel taxes in many countries and subsidies in others. The excess road deaths resulting from this are a huge human cost to the populations of these

\section{CHEAP ROADS: THE ASIAN HIGHWAY NETWORK}

One of the most ambitious road building schemes currently underway is the Asian Highway network. This 130000 kilometre road network across 31 countries is coordinated by the United Nations Economic and Social Commission for Asia and the Pacific (UNESCAP), the aim being to "promote international trade and tourism". ${ }^{9}$ The network will undoubtedly result in huge increases in road traffic throughout the region and a corresponding increase in road traffic injuries. Analyses of data from the US show that the infrastructure changes that most increased road deaths and injuries were added lane miles of road capacity and increases in the percent of lane miles that are arterial roads. ${ }^{10}$ If transport is made cheaper, in this case by providing free road space, then more of it will be consumed and there will be more road traffic injuries.

Probably the most important advance in road safety in the last century was the recognition of the need for what is known as "the systems approach". In aviation, by far the safest mode of travel, it is accepted that the operator is only one part of a dynamic system, with specific limitations and predictable error rates and that safety is best assured by designing systems with these limitations in mind. A systems approach to road safety accepts road user limitations and aims to reduce traffic crashes by designing the traffic environment with these limitations in mind.

The systems approach has important torical view of road safety is that when crashes occur they are the responsibility of the individual road user, but from a systems perspective it is those that build and operate the road system that will have the greatest impact on road safety and thus the burden of responsibility. Although UNESCAP has a duty of care to the people of the countries affected by the road network, there is little evidence that it has taken its responsibilities seriously. Safety related activities to date include sponsorship of a road safety conference, occasional publications, development of an injury surveillance database, and preparation of guidelines on accident costing. The Commission claims "ongoing regional road safety initiatives with the Global Road Safety Partnership (GRSP)" but since GRSP has projects in only three of the 31 network countries, the value of which are open to question, it would be a mistake to hold out high expectations. Indeed, here GRSP is serving its main implications for accountability. The his- 
political function of providing a fig leaf behind which global business can hide its neglect of road safety. ${ }^{11}$

Whether the Asian Highway network will bring prosperity to the rural economies of Asia remains to be seen but there is every reason for scepticism. According to UNESCAP papers "the crucial role of transport in economic development has been universally accepted". Also accepted is the fact that the economic losses associated with traffic injuries in developing countries is close to $2 \%$ of GDP, nearly US\$ 100 billion, which is twice as much as all overseas development assistance. ${ }^{11}$ These huge economic losses will undoubtedly inhibit economic development and perpetuate poverty. And who will benefit from the increased international trade? Will small rural farmers in Asia compete with the subsidised grain from American and European agribusiness? Far more likely is that the new road network will be an effective way of transferring wealth from the public purse in poor countries to private pockets in the rich with the major burden of road traffic injury falling on the poor.

\section{CHEAP FUEL: OIL WARS}

The injury control community has traditionally divided the territory into intentional and unintentional injury but in "the whole picture" the categories are blurred. Cheap transport, which generates huge numbers of "unintentional" road traffic injuries, depends on cheap oil and a large amount of intentional injury is needed to keep the oil price within acceptable limits. Oil is the quintessential strategic commodity. Speaking about Iraqi oil, the British Cabinet Minister Sir Maurice Hankey said "control over these supplies becomes a first class British war aim". That was in 1917 when wartime petroleum shortages motivated the British capture of Baghdad. ${ }^{12}$

While it could be wrong to suggest that the recent wars in Afghanistan and Iraq were entirely motivated by oil it would be foolish to claim that oil was irrelevant. Oil reserves in the Caspian Sea region are estimated at 160 billion barrels and Iraq has an estimated at 113 billion barrels. The US Department of Energy estimates that the "peacetime" military costs associated with ensuring petroleum supplies from the Middle East ranges between $\$ 6$ and $\$ 60$ billion annually. ${ }^{13}{ }^{14}$ The Gulf War in 1991 is estimated to have added an extra \$30 billion to the yearly expenses and the on-going war in Iraq is likely to prove even more costly. These costs are paid by US taxpayers as "defence" spending in order to stabilise the oil price and ensure the "efficiency" of international trade.

Although the Middle East has dominated energy security concerns in recent years, military expenditure and oil security are a global concern. Colombia provides only $2 \%$ of US oil imports but the security of these exports is a key US military objective. Colombia has long been a recipient of US military assistance but the 2003 aid package specifically included funds to protect the Caño Limón-Coveñas pipeline which is part owned by the US based Occidental Petroleum. "Securing" the pipeline is estimated to represent a $\$ 3.70$ per barrel corporate subsidy paid by US taxpayers. ${ }^{15}$

The importance of oil in foreign policy is also highlighted in UK government papers released this year under the 30 year rule, showing that the US considered using force to seize oil fields in the Middle East during the 1973 Arab oil embargo which had thrown the global economy into crisis. ${ }^{16}$ According to the British Government, US defence secretary James Schlesinger said that "it was no longer obvious that the US could not use force", to bring the oil crisis to an end.

\section{SUMMARY}

Economic globalisation is a new term for an age old activity. For centuries, countries with greater economic and military power have sought access to the resources and markets of weaker countries and many people have died in the process. The powerful countries claim that "trade" benefits both the stronger and the weaker economies but the historical record suggests otherwise.
In his trenchant economic history of Latin America, the Uruguayan journalist Eduardo Galeano explains how his continent's transportation infrastructure was developed to drain its wealth into the ports and then out to the colonial economy. ${ }^{17}$ Whether the Asian Highway network will have a similar effect remains to be seen but the injury control community can no longer overlook the consequences of macroeconomic policies that are shaping our world.

Injury Prevention 2004;10:65-66. doi: 10.1136/ip.2004.005140

Correspondence to: Professor lan Roberts, London School of Hygiene and Tropical Medicine, 49-51 Bedford Square, London WCIB 3DP, UK; ian.roberts@lshtm.ac.uk

\section{REFERENCES}

1 US Department of Transportation. Highway statistics. Washington, DC: Federal Highway Administration, 1994-2000.

2 Eurostat. Statistics in focus: trends in road freight transport 1990-1999. European Communities, 2002.

3 UK Department of Transport. Heavy goods vehicles in road accidents: Great Britain 1998. London: Department of Transport, 1999

4 Crash Foundation. Available at: http:// www.trucksafety.org.

5 Gilbert K, McCarthy M. Deaths of cyclists in London 1985-92: the hazards of road traffic BMJ 1994;308:1534-7.

6 Mohan D. Work trips and the safety of bicyclists. Indian Journal of Transport Management, AprilJune, 2002:225-32.

7 Roberts I, Marshall R, Norton R. Child pedestrian mortality and traffic volume in New Zealand. BMJ 1992;305:283

8 Roberts I, Crombiel. Child pedestrian deaths: sensitivity to traffic volume - evidence from the USA. J Epidemiol Community Health 1995;49:186-8.

9 United Nations Economic and Social Commission for Asia and the Pacific. Available at: http:// www.unescap.org/tctd/ah/.

10 Noland RB. Traffic fatalities and injuries: the effects of changes in infrastructure and other trends. Accid Anal Prev 2003;35:599-611.

11 Global Road Safety Partnership. Available at: http://www.grsproadsafety.org/

12 Yergin D. The prize. New York: Simon \& Schuster, 1992

13 International Council for Local Environmental Initiatives. Available at: www.iclei.org/efacts/ economic.htm.

14 Delucchi M, Murphy J. US military expenditures to protect the use of Persian Gulf oil for motor vehicles. Davis, CA: Institute of Transportation Studies, April 1996

15 American Friends Service Committee. Available at: http://www.afsc.org/colombiaoil/.

16 Bowcott O. Heath feared US plan to invade Gulf. Guardian 1 January 2004.

17 Galeano E. Open veins of Latin America. New York: Monthly Review Press, 1997. 